\title{
PERANAN STAF DALAM PENGAMBILAN KEPUTUSAN OLEH PIMPINAN PERGURUAN TINGGI
}

\author{
Oleh: Arifuddin S.*
}

\begin{abstract}
In practice, some leaders of higher educational institutions have not realized the importance of both academic and administrative staffs' participation in decision making. It is argued that the staff members of higher education learning play a very important role in decision making process. Their participation would contribute more perspectives to produce good decision. It also encourages creativeness and commitment of staff members. These are crucial factors to improve work motivation of staff members in developing their institution and increasing productivity.
\end{abstract}

KEYWORDS: Staf, keputusan, pimpinan, perguruan tinggi

BILA dilihat dari konsersium bidang ilmu, maka penulis berkeyakinan bahwa manajemen pendidikan termasuk dalam konsersium bidang Ilmu Pendidikan. Banyak kalangan yang tidak memperhitungkan betapa besar peranan Manajemen Pendidikan dalam mewujudkan pelaksanaan pendidikan yang efisien dan efektif.

Salah satu fungsi Manajemen Pendidikan yang tak kalah pentingnya untuk dibicarakan adalah "fungsi pengambilan keputusan". Tulisan ini berjudul "Peranan Staf dalam Pengambilan Keputusan oleh Pimpinan Perguruan Tinggi." Agar tidak menimbulkan persepsi yang lain, maka penulis menegaskan tiga kata kunci dalam tulisan ini sebagai berikut.

\section{Staf}

Dalam Ilmu Administrasi Pendidikan atau Ilmu Manajemen Pendidikan kata staf berarti personalia organisasi (termasuk organisasi lembaga pendidikan). Itulah sebabnya staffing dari kata staff diartikan oleh T. Hani Handoko "penyususnan personalia". ${ }^{1}$ Kata personalia, adalah semua tenaga atau SDM organisasi yang meliputi: dosen, pustakawan, laboran,

*Magister Pendidikan dalam bidang Manajemen Pendidikan dari Universitas Negeri Malang ini adalah dosen pengampu mata kuliah Ilmu Pendidikan pada Fakultas Tarbiyah dan Keguruan UIN Alauddin Makassar. Saat ini ia sedang menjabat sebagai Wakor Kopertais Wilayah VIII Sulawesi, Maluku, dan Papua. 
sebagai tenaga funsional; karyawan sebagai tenaga struktural; staf ahli sebagai tenaga khusus, dan lain-lain. Seluruh staf (personalia) perguruan tinggi tersebut adalah merupakan pendukung utama organisasi perguruan tinggi.

Dalam manajemen moderen, staf tidak hanya unsur pelaksana dari implementasi keputusan, tetapi juga menjadi unsur penting yang harus ikut serta dalam proses pengambilan keputusan. Pengambilan keputusan yang hanya dilakukan oleh pimpinan tanpa melibatkan staf, maka pendekatan ini disebut top down, otoriter. Memang pendekatan top down oleh sebahagian praktisi manajemen tidak ditinggalkan, tetapi dipadukan dengan pendekatan bottom up, dimana pimpinan dan staf bersama-sama dalam proses pengambilan keputusan. Itulah sebabnya dalam rapat senat yang diperluas di universitas misalnya, diikuti oleh Rektor, para Pembantu Rektor, para Dekan, para Guru besar, Dosen yang mewakili jurusan, para Kepala Biro (sebagai tenaga struktural).

\section{Pengambilan Keputusan}

Pengambilan keputusan yang penulis maksudkan adalah apa saja yang diputuskan oleh pimpinan perguruan tinggi, baik keputusan strategis pada level pimpinan tingkat tinggi, keputusan taktis pada level pimpinan tingkat menengah, maupun keputusan operasional pada level pimpinan tingkat bawah (first line leader).

\section{Pimpinan Perguruan Tinggi}

Dalam tulisan ini sengaja penulis tidak memberi batasan pada satu tipe perguruan tinggi. Hal ini dimaksudkan agar ketika menyebut pimpinan perguruan tinggi, maka yang dituju adalah pimpinan perguruan tinggi untuk semua tipe (Universitas, Institut, Sekolah Tinggi, Fakultas, Akademi).

\section{PENGERTIAN DAN PROSES PENGAMBILAN KEPUTUSAN}

Beraneka situasi yang menuntut pengambilan keputusan senantiasa muncul dalam kehidupan sehari-hari, di dalam organisasi (lembaga pendidikan) tempat kita bekerja, di dalam masyarakat tempat kita hidup. Penggarapan keputusan-keputusan itu merupakan sebahagian besar dari tungas seseorang pada tiap tingkat dalam suatu organisasi moderen. Ada di antara situasi itu dijumpai berulangkali dan pada hakekatnya memiliki bentuk yang serupa pada setiap peristiwa. Situasi semacam ini dapat digarap secara efektif dengan menuruti kaedah-kaedah dan pola keperilakuan yang telah dimantapkan berdasarkan pengalaman sebelum-nya. 
Ada pula sebahagian situasi yang pernah dijumpai namun mungkin terdapat ciri-ciri khas pada masalah yang baru timbul yang berbeda dalam beberapa aspek penting. Ada pula situasi yang semata-mata baru dan unik dalam segala aspeknya.

Manajemen perguruan tinggi sebagaimana manajemen organisasi lainnya, juga terdapat masalah khas, baik yang menyangkut pengelolaan pengajaran, pengelolaan kemahsiswaan, pengelolaan personalia, pengelolaan keuangan, perngelolaan sarana dan pra sarana, dan pengeloalan hubungan lembaga dan masyarakat. Untuk mengatasi masalah-masalah tersebut, bukanlah tugas yang sederhana melainkan tugasnya cukup kompleks dan membutuhkan suatu tanggung jawab kepemimpinan, serta kemampuan manajerial untuk mempertimbangkan dan menetapkan alternatif pemecahan. Kegiatan menetapkan alternatif pemecahan, kegiatan menetapkan atau memutuskan sesuatu, secara inplisit mengandung makna adanya upaya menemukan kesepakatan dalam rangka pelaksanaan tugas.

Pengambilan keputusan secara rinci merupakan suatu proses aktivitas berpikir logis. Sebagai aktivitas logis pengambilan keputusan dapat digeneralisasikan dalam serentetan peristiwa atau kegiatan yang bertahap. Menurut Hoy dan Miskel terdapat lima tahap kegiatan dalam pengambilan keputusan yaitu: (1) merumuskan masalah, (2) mengidentifikasi alternatif pemecahan, (3) menentukan kriteria, (4) menguji alternatif pemecahan, dan (5) memilih alternatif yang terbaik sebagai keputusan untuk dilaksanakan. ${ }^{2}$

Apabila setiap aktivitas proses pengambilan keputusan itu dilalui secara cermat dan teliti, maka keputusan yang tepat diharapkan bisa diperoleh. Proses pengambilan keputusan dengan melalui aktivitas tersebut, dikenal dengan istilah "proses yang analisis" atau "proses yang rasional". Pengambilan keputusan dengan proses analisis inilah yang dapat dipergunakan untuk meramalkan keefektifan organisasi. Sebaliknya pimpinan dalam menghadapi masalah dapat mengambil keputusan tampa memperhatikan aktivitas-aktivitas bertahap itu, keputusan diambil secara cepat tanpa dipikirkan secara matang, sehingga memberikan kesan dilakukan secara spekulatif dan acak-acakan. Proses ini dikenal dengan istilah "proses yang tidak rasional" atau "proses lateral". Dan proses ini tidak dapat dijamin bahwa keputusan yang efektif bisa diperoleh.

Dalam praktek organisasi di beberapa lembaga perguruan tinggi, pimpinan belum menyadari betapa pentinnya partisipasi staf (dosen dan karyawan) dalam pengambilan keputusan. Staf hanya dianggap pekerja operasional yang tidak perlu ikut dalam proses pengambilan keputusan.

Dari uraian tersebut di atas, maka yang menjadi permasalahan adalah bagaimanakah peranan staf dalam pengambilan keputusan? 


\section{Pengertian Pengambilan Keputusan}

Untuk mengungkapkan pengertian pengambilan keputusan maka dikemukan pandangan para ahli, meskipun pengertian itu bervariasi, tetapi dalam uraian ini diupayakan menemukan dasar-dasar persamaan dari pandangan para ahli tersebut.

Steiner mendefinisikan pengambilan keputusan sebagai berikut:

Sebagai suatu proses manusiawi yang disadari dan mencakup baik fenomena individu maupun sosial, didasarkan pada premis nilai dan fakta, menyimpulkan sebuah pilihan dari antar alternatif dengan maksud bergerak menuju suatu situasi yang diinginkan. ${ }^{3}$

Steers dalam Mulyadi mengemukakan bahwa "decision making is a process of selecting among available alternatives". ${ }^{4}$ Di sini jelas bahwa pengambilan keputusan menyangkut pilihan dari berbagai macam alternatif yang ada dalam organisasi. Selanjutnya Koontz mengatakan bahwa pengambilan keputusan merupakan seleksi berbagi alternatif tindakan yang akan ditempuh merupakan inti perencanaan. ${ }^{5}$ Senada dengan pendapat tersebut, William mendefinisikan pengambilan keputusan sebagai seleksi berbagai alternatif kegiatan yang diusulkan untuk memecahkan masalah. ${ }^{6}$

Berdasarkan pandangan-pandangan tersebut di atas, dapat difahami bahwa pengambilan keputusan senantiasa berkaitan dengan problem atau masalah dalam organisasi, sifat hakiki dari pengambilan keputusan adalah memilih satu dua atau lebih alternatif pemecahan masalah menuju satu situasi yang diingingkan, melalui keputusan atau penetapannya orang berharap akan tercapai suatu pemecahan masalah dari problem yang terjadi.

Pada dasarnya ada dua pendekatan dalam pengambilan keputusan, yaitu: (1) pendekatan ilmiah (scientific approach), di mana dapat dipelajari beberapa alternatif dan memprediksi hasil dari setiap alternatif; (2) pendekatan coba dan ralat (trial and error), yaitu mencoba alternatif dan melihat apa yang terjadi, berusaha mencapai tujuan, tetapi jika tidak berhasil, maka dapat dicoba kembali.

Setiap pengambilan keputusan tentu disertai dengan konsekuensi, sehingga seorang pengambil keputusan perlu memperhatikan beberapa hal sebagai berikut:

1. Kejelasan tujuan

Proses pengambilan keputusan mempersyaratkan kejelasan arah dan tujuan organisasi. Pemahaman akan tujuan baik tujuan jangka panjang maupun tujuan jangka pendek, sangat membantu dalam memanfaatkan 
dan menetapkan prioritas sehingga tidak perlu mengambil tindakan yang kurang bermanfaat.

\section{Kebutuhan akan fakta}

Pengambilan keputusan merupakan proses yang berkesinambungan. Setiap langkah yang diambil merupakan selangkah maju. Artinya apabila langkah pertama menghadapi masalah, beberapa tindakan harus diambil maka pada langka kedua benar-benar memahami masalah dan situasi yang dihadapi. Untuk itu pada pengambilan keputusan administrator/manajer perlu mengumpulkan fakta. Semakin banyak fakta semakin sedikit waktu yang digunakan dalam pengambilan keputusan.

3. Secara teori dalam pengambilan keputusan, harus mempertimbangkan berbagai alternatif

\section{Menyeleksi tindakan}

Seleksi tindakan dapat dilakukan melalui vooting, konsensus atau keputusan administrator/manajer sendiri. Tindakan terbaik untuk melakukan pemecahan masalah adalah tindakan yang mengarah pada pencapaian tujuan organisasi. Seleksi tindakan dalam pengambilan keputusan sangat berkaitan dengan gaya pribadi, nilai, kepercayaan, skil, dan lain-lain.

Dari uarain yang dikemukan di atas, jelas bahwa pengambilan keputusan sangat penting dalam memecahklan masalah, bahkan sebagai inti kegiatan manajemen. Sehubungan dengan hal ini Mintzberg mengemukakan bahwa:

Salah satu fungsi pokok pimpinan dalam manajemen adalah fungsi pengambilan keputusan untuk menyelesaikan masalah. Dengan demikian maka seorang pimpinan dalam pengambilan keputusan perlu memiliki pikiran dan kehati-hatian, karena ia harus membawa organisasi kearah tujuan yang ingin dicapai bersama. Ia juga harus mampu memilih berbagai alternatif yang terbaik, sehingga dituntut pula kemampuan analisis untuk memilih pemecahan masalah yang rasional. ${ }^{7}$

\section{Proses Pengambilan Keputusan}

Terkait dengan proses pengambilan keputusan ini, Guthria dan Reed mengemukakan bahwa:

Dalam proses pengambilan keputusan, rencana dipilih sedikitnya dari dua atau lebih alternatif. Pembuatan keputusan itu sendiri mengikuti langkah yaitu: menentukan masalah, menganalisa komponen-komponen, mengembangkan strategi atau alternatif untuk memecahkan masalah, memilih alternatif yang paling baik, mengembangkan dan mengimplementasikan suatu rencana, tindakan, mengevaluasi keefektifan rencana dan mengulangi kembali langkah-langkah ini bila diperlukan. ${ }^{8}$ 
Proses di atas menggambarkan suatu pendekatan rasional pada pembuatan keputusan. Namun, tidak semua keputusan yang dihasilkan mendatangkan kepuasan. Keterbatasan pemikiran atau pengetahuan, semua kemungkinan alternatif yang ideal merupakan kesulitan pengambilan keputusan. Keputusan-keputusan yang dicapai akan mendatangkan kepuasan jika didasari oleh pengetahuan akan alternatif untuk mencapai hasil yang maksimal.

Oteng Sutisna mengemukakan:

Proses pengambilan keputusan adalah suatu usaha yang rasional dari adminisrator untuk mencapai tujuan-tujuan yang telah ditetapkan pada bagian awal dari fungsi perencanaan. Prosesnya mulai dan berakhir dengan pertimbangan. Ia memerlukan kreaktivitas, keterampilan kuantitatif dan pengalaman. Urutan langkah-langkahnya ialah: (1) penentuan masalah, (2) analisa situasi yang ada, (3) pengembangan alternatif-alternatif, (4) analisa alternatif-alternatif, dan (5) pilihan alternatif yang paling baik. ${ }^{9}$

Wenrich \& Wenrich menyebutkan tiga langkah yang perlu diperhatikan dalam proses pengambilan keputusan, yaitu: (1) identifikasi masalah, (2) pemecahan masalah, (3) mengidentifikasi akibat-akibat, dan memilih alternatif yang terbaik. ${ }^{10}$

Sebenarnya tidak banyak putusan yang dibuat dengan memakai urutan tindakan yang lengkap dan sempurna. Masalahnya mungkin demikian jelas sehingga membuat perumusan tidak perlu. Sering tidak banyak usaha dibuat untuk menyajikan atau mempertimbangkan faktafakta. Prasangka sering menghasilkan alternatif-alternatif yang sangat dangkal, dan pertimbangan mungkin dirintangi oleh nilai-nilai yang tidak diperinci atau ketidaksanggupan untuk berpikir secara srategis, atau pengaruh politik.

Walaupun diakui bahwa keputusan-keputusan organisasional dipengaruhi oleh faktor-faktor politik, tingkat pendidikan dan lainnya namun konsep proses pengambilan keputusan yang rasional tetap dijadikan dasar dari keputusan-keputusan. Sebahagian besar pengambil keputusan lembaga pendidikan (termasuk lembaga pendidikan tinggi) lebih suka untuk memikirkan dimana keputusan yang dibuat didasarkan pada analisis rasional dari alternatif, dan pemilihan dari tindakan atau pemecahan secara optimal serta akibatnya pada lembaga. Namun, alternatif yang masuk akal dapat juga dipandang dari hubungannya dengan macam tekanan, baik yang mendukung maupun yang menentangnya. Akibatnya sebahagian besar keputusan dibuat pada suasana kekuatan dan kekurangan yang bertentangan, sehingga pengambilan keputusan seringkali 
menjadi seni persetujuan. Disinilah pendekatan rasional sering mengalami kegagalan untuk memperhitungkan realitas secara politis, dan berbagai macam keiginan serta pengaruh para partisipan sehingga pemecahan masalah sering melalui kompromi untuk mencapai keputusan.

Oteng Sutisna mengatakan:

Putusan yang paling baik seperti yang dihasilkan oleh suatu model putusan, mungkin tidak dipilih oleh para pembuat putusan melainkan putusan yang dapat diterima. Putusan ini secara matematis, statistis atau finansial mungkin tidak benar, tetapi ia lebih akseptabel secara emosional, etis dan politis, dan juga dapat mudah di fahami di semua tingkat organisasi.11

Berdasarkan urain di atas, maka dapat dipahami bahwa proses pengambilan keputusan terdiri dari berbagai tindakan yang memanfaatkan berbagai ragam keterampilan dan pengetahuan yang diperoleh dari pengalaman dalam kehidupan berorganisasi. Dalam proses pengambilan keputusan mau tidak mau harus diperhatikan pula nilai-nilai moral serta etika. Dalam proses pengambilan keputusan, karena manusia memainkan peranan yang paling menentukan, maka filsafat hidup, nilai-nilai yang dianut, latar belakang pendidikan pengalaman, pandangan dan prestasi seseorang turut pula berperan. Dengan semua faktor tersebut pun masih tetap tidak ada kepastian bahwa keputusan yang diambil benar-benar akan mendatangkan hasil yang diharapkan. Itulah sebabnya kalau orang berbicara tentang probabilitas, baik yang menyangkut keberhasilan maupun ketidakberhasilan.

\section{PARTISIPASI STAF DALAM PENGAMBILAN KEPUTUSAN}

Pembicaraan mengenai partisipasi staf dalam pengambilan keputusan memerlukan pembedaan antara putusan tentang pembentukan kebijaksanaan dengan putusan tentang pelaksanaan kebijaksanan. Dalam organisasi yang demokratis setiap orang yang berkepentingan hendaknya diberi kesempatan untuk menyatakan pandangannya mengenai soal-soal kebijaksanaan, tetapi pelaksanaan kebijaksanaan adalah tanggung jawab dari pejabat-pejabat eksekutif. Jadi implementasi putusan-putusan kebijaksanaan adalah tanggung jawab seseorang administrator.

Menurut Sudjana dan Susanta bahwa:

Mutu keputusan yang diambil sangat tergantung pada: (1) tepat tidaknya definisi yang dibuat tentang hakekat situasi problematik yang dihadapi; (2) tersedianya informasi yang mutakhir, lengkap dan dapat dipercaya; (3) mampu tidaknya mengidentifikasi berbagai alternatif yang akan ditempuh; (4) mampu tidaknya analisis yang dilakukan terhadap tiap alternatif; dan (5) berani tidaknya kelompok mengambil resiko dalam suasana ketidakpastian..$^{12}$ 
Mutu keputusan dan partisipasi staf (dosen dan karyawan) dalam proses pengambilan keputusan sangat penting dan mutlak, sehingga pimpinan dapat berperan dengan lebih baik selaku dinamisator, integrator, dan fasilitator.

Sondang P. Siagian berpendapat bahwa:

Untuk dapatnya diterima keputusan oleh semua pihak maka mutlak diperlakukan syarat sebagai berikut: (1) terutama mereka yang nanti terlibat dalam pelaksanaanya; (2) adanya kesempatan yang cukup pada staf (dosen dan karyawan) yang menyelesaikan sendiri masalah yang timbul melalui berbagai langkah dalam proses pengambilan keputusan; (3) bagi pihak yang merasa dirugikan perlu diberikan keyakinan bahwa keputusan itu adil, dilihat dari kepentingan lembaga pendidikan atau organisasi; (4) keputusan itu didasari atas skala prioritas yang jelas, seperti mendahulukan hal yang penting serta waktu, tenaga, pikiran, informasi, dan sumber daya dimanfaatkan dengan efektif dan efesien. ${ }^{13}$

Guithrie dan Reed mengatakan bahwa "partisipasi dan keikutsertaan anggota staf, selain memungkinkan penerimaan keputusan semakin besar, juga kreativitas terdorong dan komitmen anggota semakin kuat."14 Selanjutnya Mangkusubroto dan Trisnadi juga mengungkapkan bahwa "dalam pengtambilan keputusan, kualitasnya sangat didukung oleh partisipasi anggota kelompok."15

Diketahui bahwa sejumlah alternatif lebih banyak dikembangkan serta dianalisis dalam kelompok, sehingga keputusan lebih berkualitas, analisis sejumlah alternatif yang membuat partisipasi dalam proses pengambilan keputusan menjadi bernilai. Partisipasi staf di lain pihak tidak perlu sampai membuat anggota staf baik dosen maupun karyawan tidak dapat mengambil keputusan sendiri. Membuat keputusan sendiri juga sangat berarti bagi staf terutama dosen, karena hal ini sebagai pertanda adanya kepercayaan pimpinan lembaga pendidikan sebagai pengambil keputusan (decision maker).

Anggota staf yang ingin mengembangkan kreativitasnya dan melakukan inovasi di dalam lembaganya, perlu mendapat perhatian pimpinan lembaga pendidikan yang bersangkutan dalam kaitannya dengan program pengembangan karier. Menurut Owens bahwa "banyaknya keuntungan yang dapat dicapai melalui keikutsertaan dan partisipasi staf, antara lain dicapainya keputusan yang jauh lebih baik dan dapatnya dipertinggi pertumbuhan dan perkembangan anggota dalam organisasi."16

Memang kebanyakan administrator dalam perbagai tipe organisasi masih meragukan perlunya keikutsertaan atau penggunaan orang lain 
dalam pengambilan keputusan. Kenyataan selanjutnya menunjukkan bahwa banyak organisasi yang berkembang menjadi maju dan berhasil karena menggunkana kekuatan kelompok. Meskipun demikian, peranan kelompok sebagai sarana kerja sama dalam lembaga atau organisasi tidak asal jadi. Dalam kaitan ini paling tidak menurut Owens bahwa: harus memperhatikan dua faktor, yaitu: (1) Kebutuhan adanya proses pengambilan keputusan yang jelas, dan (2) adanya kriteria untuk memasukkan orangorang dalam suatu proses tersebut. ${ }^{17}$

Dengan demikian, keberadaan anggota staf dalam pengambilan keputusan banyak ditentukan oleh pimpinan selaku administrator.

Melihat rincian kegiatan yang kompleks dalam proses pengambilan keputusan, secara analitis Hoy dan Miskel melihat betapa pentingnya keikutsertaan dan kerja sama pimpinan lembaga pendidikan dengan staf (dosen dan karyawan) sesuai dengan situasi lembaganya. Mereka meringkaskan sejumlah hasil penelitian tentang kerja sama guru dan karyawan dalam proses pengambilan keputusan yang intinya:

(1) Adanya kesempatan untuk ikut merumuskan kebijakan, merupakan faktor penting bagi peningkatan moral kerja guru dan karyawan, dan menjadikan mereka antusias atau bersemangat terhadap organisasi sekolahnya; (2) Keterlibatan dalam pengambilan keputusan mempunyai hubungan yang positif dengan kepuasan diri guru dan karyawan dalam profesinya; (3) Guru dan karyawan baik yang sekedar ingin diikutkan dalam sebahagian pengambilan keputusan atau yang ingin dilibatkan dalam keseluruhan aktivitas pengambilan keputusan, dalam kenyataanya dapat memberikan sumbangan terhadap kepala sekolah dalam melakukan proses pengambilan keputusan; (4) Ketidakefektifan guru dan karyawan dapat terjadi karena mereka tidak diterima secara penuh dalam sistem sekolah dan karena rendahnya kualitas kerja sama terhadap keputusan yang diambil. ${ }^{18}$

Each dan French dalam penelitiannya telah lama melihat sumbangan keterlibatan atau keikutsertaan pengawai disebuah pabrik milik negara di kota Harwood, USA. Hasil penelitian itu menunjutkan bahwa keterlibatan pengawai dalam pengambilan keputusan dapat meningkatkan produktivitas kerja sama mereka.

\section{PENUTUP}

\section{Kesimpulan}

Berdasarkan apa yang telah diuraikan di atas, maka dapat ditarik kesimpulan bahwa staf (dosen dan karyawan) dalam suatu lembaga pendidikan tinggi mempunyai peranan yang sangat penting dalam memberikan sumbangan tenaga dan pikiran pada proses pengambilan 
keputusan yang pada gilirannya meningkatkan kegairahan dan unjuk kerja sehingga lembaga pendidikan tinggi dapat mencapai kemajuan dan produktivitas serta hasil yang memuaskan.

\section{Saran}

Pimpinan perguruan tinggi di semua level penting sekali memiliki pengetahuan dan keterampilan manajerial, terutama yang berkaitan dengan pelaksanaan fungsi-fungsi manajemen termasuk fungsi pengambilan keputusan. Oleh karena itu, disarankan secara berkesinambungan selalu mengupayakan pelatihan Manajemen Pendidikan.

\section{CATATAN AKHIR:}

1. T. Hani Handoko, Manajemen, edisi 2, Yogyakarta: BPFE, 1995, h. 234.

2. Lihat Hoy and Miskel, Educational Administration: Theory, Research and Practice, Now York: Random House, Inc., 1987, h. 78.

3. George A. Steiner, Kebijakan Strategi Manajemen, diterjemahkan oleh Tim Dosen Manajemen pada Fakultas Ekonomi Universitas Indonesia, Jakarta: Erlangga, 1988, h. 9.

4. Muhyadi, Organisasi Teori, Struktur, dan Proses, Jakarta: Dirjen Dikti Dikbud, 1989, h. 47.

5. Kontz, Manajemen, diterjemahkan oleh Tim Dosen Manajemen pada Fakultas Ekonomi Universitas Indonesia, Jakarta: Erlangga, 1988, h. 13.

6. Wanrich J. William, Leadership in Administration, of Vocational and Tehnical Education, Ohio: Charles, E. Merril Publishing Company A Bell \& Howell Company, 1992, h. 113.

7. Mintzberg J., Dimensi Kepemimpinan dalam Manajemen, diterjemahkan oleh wiriadihardja, Bandung: Trasito, 1987, h. 56.

8. Guthria and Reed J. Rodney, Educational Administration and Policy Effective Leadership of American Education, New Jersey: Prentice Hall Inc., 1982, h. 69

9. Oteng Sutisna, Administrasi Pendidikan Dasar Teoritis untuk Praktek Profesional, Bandung: Angkasa, 1983 h. 151.

10. Wenrich, J. William, Leadership in Administration of Vocational and Technical Education, h. 113.

11. Oteng Sutisna, Administrasi Pendidikan Dasar Teoritis untuk Praktek Profesional, h. 153.

12. Sujana dan Susanta, Pendekatan Sistem Bagi Administrator Pendidikan, Bandung: Sinar Baru, 1989),h. 68

13. Sondang P. Siagian, Sistem Imformasi untuk Pengambilan Keputusan, (Jakarta: SV. Haji Masagung, 1990, h. 215.

14. Guthria and Reed J. Rodney, Educational Administration and Policy Effective Leadership of American Education, h. 73.

15. Mangku Subroto dan Trisnadi, Analisis Keputusan, Bandung: Ganesa Exact ITB Bandung, 1987, h. 20. 
16. Owens, Organization Behavior in Education, Engliwood Cliffs, New Jersey: Prentice Hall, Inc., 1987, h. 432.

17. Owens, Organization Behavior in Education, h. 410.

18. Hoy and Miskel, Educational Administration: Theory, Research and Practice, h. 86.

\section{DAFTAR PUSTAKA:}

Handoko, T. Hani, Manajemen, edisi 2, Yogyakarta: BPFE, 1995.

Hoy and Miskel, Educational Administration: Theory, Research and Practice, Now York: Random House, Inc., 1987.

Steiner, George A., Kebijakan Strategi Manajemen, diterjemahkan oleh Tim Dosen Manajemen pada Fakultas Ekonomi Universitas Indonesia, Jakarta: Erlangga, 1988.

Muhyadi, Organisasi Teori, Struktur, dan Proses, Jakarta: Dirjen Dikti Dikbud, 1989.

Kontz, Manajemen, diterjemahkan oleh Tim Dosen Manajemen pada Fakultas Ekonomi Universitas Indonesia, Jakarta: Erlangga, 1988.

William, Wanrich J., Leadership in Administration of Vocational and Tehnical Education, Ohoi: Charles E. Merril Publishing Company A Bell \& Howell Company, 1992.

Mintzberg J., Dimensi Kepemimpinan dalam Manajemen, diterjemahkan oleh wiriadihardja, Bandung: Trasito, 1987.

Guthria and Reed J. Rodney, Educational Administration and Policy Effective Leadership of American Education, New Jersey: Prentice Hall Inc., 1982.

Sutisna, Oteng, Administrasi Pendidikan Dasar Teoritis untuk Praktek Profesional, Bandung: Angkasa, 1983.

Sujana dan Susanta, Pendekatan Sistem Bagi Administrator Pendidikan, Bandung: Sinar Baru, 1989.

Sondang P. Siagian, Sistem Informasi untuk Pengambilan Keputusan, Jakarta: SV. Haji Masagung, 1990.

Mangku Subroto dan Trisnadi, Analisis Keputusan, Bandung: Ganesa Exact ITB Bandung, 1987.

Owens, Organization Behavior in Education, Engliwood Cliffs, New Jersey: Prentice Hall, Inc., 1987. 